\title{
Relevance of German Political Foundations for Comparative Educational Research
}

\author{
Christel Adick* and Maria Giesemann \\ Ruhr-University Bochum, Germany
}

\begin{abstract}
German political foundations, mainly Friedrich-Ebert-Stiftung (FES) and KonradAdenauer-Stiftung (KAS), have a long tradition of political activism in Germany as well as internationally. Founded after the Second World War, their mission was and is the promotion of democracy and civic education. Likewise, they pursue these educational goals abroad, where they have been active for over 50 years. But despite many years of experience in the field of political education across borders, the foundations have hardly been noticed in educational research. Therefore, an international audience shall be made aware of the unique characteristics of the German party related political foundations as actors in the world. This article will address the international dimensions of these organizations: how they operate across borders and what they offer in their educational dimensions. This will show their close entanglement with the official German foreign policy and with the political parties to which they are affiliated in Germany.
\end{abstract}

Keywords: German political foundations, cross-border education, political/civic education

\section{Introduction}

Even though German political foundations, namely Friedrich-Ebert-Stiftung (FES) and Konrad-Adenauer-Stiftung (KAS), are quite well known among politicians and academics around the world, they are under-researched in the broad landscape of Social and Political Sciences and nearly completely unknown in Educational Sciences. And even though these foundations date back some 70 years to the period after the Second World War and their international work began in the 1960s, they have not been covered much by research. Furthermore, and most importantly for this article, even though their main reason of existence is 'political education' and despite the fact that they operate across borders in practically every second country of the world ${ }^{1}$, so far no attention has been paid to them in Comparative Education. 
From these basic facts derives the main message of this article that the German political foundations could and should attract debates and research on their ways of performing educational transfers across borders. More specifically, it wants to give an insight into the educational dimensions of their work. ${ }^{2}$ The authors want to highlight what seems to be 'typical' for the education of these organizations and give ideas for challenging future research perspectives especially in areas of Comparative Education. By placing special attention to existing literature in English, scholars also from non-German speakingbackgrounds are encouraged to take an interest in these very specific realities of Germany's international educational cooperation.

The article at first discusses why German political foundations are at all relevant for educational research. Following this, existing literature will be reviewed to characterize the nature of these organizations. The next step will be to categorize the type of education they offer by highlighting some evidence from the existing, though scarce, research. The article concludes with the main characteristics of the educational set-up of these organizations and depicts areas of future research deemed especially attractive for international comparative educational researchers.

\section{Relevance of Education as Part of German Political Foundations}

Why could the German political foundations be of interest especially to the field of Comparative Education? The following three reasons will be highlighted: their longevity, their world-wide presence and not least their educational mission.

One of the reasons for being potentially attractive for research is the (relative) longevity of these organizations. With the exception of the FES, which originated in 1925 and was re-established in 1947, this type of organization has been created after the Second World War and later on as a corollary of upcoming new political parties. As mentioned, the FES is the oldest such organization, followed by the KAS, which emerged in 1964 from the 'Society for Christian-Democratic Civic Education', established in 1955. The FriedrichNaumann-Stiftung (FNS), which is close to the Liberals, was founded in 1958. Three years after KAS was born, the Hanns-Seidel-Stiftung (HSS) was established in 1967 with its goal to promote political education based on Christian principles. It was ideologically close to the Christian Social Union based in Bavaria. In 1997, the Heinrich-Böll-Stiftung (HBS), which is related to the Greens, has emerged from Stiftungsverband Regenbogen, the umbrella organization of three other foundations. The sixth and at present the youngest German political foundation is the Rosa-Luxemburg-Foundation (RLS), associated with the politics of the Left based on democratic socialism; it was officially founded in 2000, but it had been politically active since 1990 .

At first these political foundations were predominantly active in Germany, because their main duty was promoting democracy and political (re-)education for the Germans after the Hitler regime and the Second World War. But their turn to a democratizing mission across 
national borders followed after the establishment of the Federal Ministry for Economic Cooperation and Development (German acronym: BMZ) in 1961. The BMZ supported the political foundations with financial resources in order to provide socio-political education aid in developing countries (Egger, 2007, p. 40). Some of these foundations were already in contact with several umbrella organizations abroad, i.e. with international party associations and federations of trade unions (Pogorelskaja, 2009b, p. 31). Along with BMZ, the Federal Foreign Office (German acronym: AA) has funded the foundations since 1960s in order to provide support to intellectually gifted people from developing countries (Pogorelskaja, 2009b, p. 32). These facts reveal the strong interconnectedness of the political foundations' work abroad to German foreign policy goals right from the beginning. Their first offices abroad were founded in the 1960s in African, Asian and Latin American countries (Pogorelskaja, 2002, p. 31). For instance, one of the first foreign offices of KAS (1967) and FES (1969) was established in Mexico, so these foundations have nearly 50 years of experience in working in that country. Other foundations followed their lead and established field offices abroad in the decades which followed.

The second reason why the work of these foundations is of interest to researchers in Comparative Education is that while they are rather well known in diplomatic, academic and politically active circles around the world, they have stayed completely unnoticed in international educational research up to now. Their wide distribution around the globe could attract the attention of international scholars.

Our analysis of the foundations' web pages and annual reports of 2011 revealed that all six political foundations are present with 305 offices in 109 countries of the world. Illustrating their presence on a world map, Figure 1 shows that there are only few parts of the world where they are not located. Considering the 193 countries presently organized under the umbrella of the United Nations (UN), it can be observed that in $56 \%$ of the countries, at least one German political foundation was operating a branch office in 2011. Compared to the distribution of the 153 German Embassies around the world (without Consulates General and Consulates), German political foundations are the second most widespread German foreign representations. 


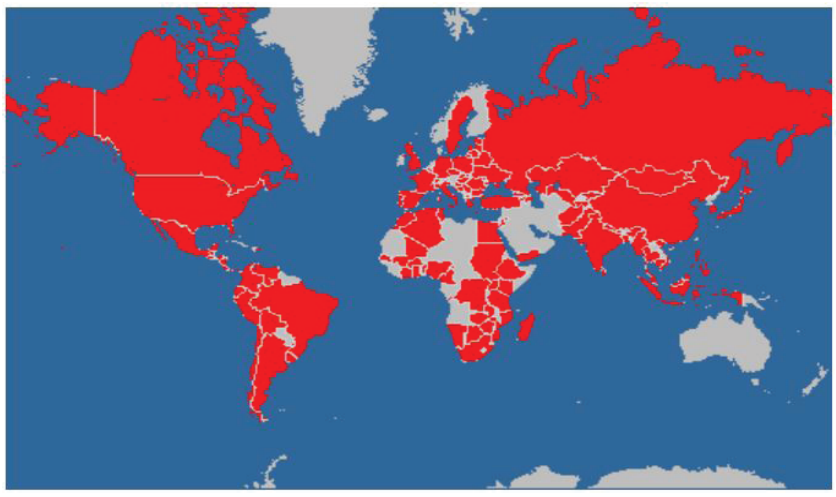

country highlighted in dark grey $=$ at least one office of a German political foundation Figure 1. Worldwide distribution of German political foundations (Source: Own illustration).

The continent with most offices abroad is $\mathrm{Asia}^{3}$ (93 offices in 34 Asian countries), followed by Europe ( 84 offices in 28 countries). The third largest number of offices are situated in Africa ( 70 offices in 27 countries). In the North and South American countries, the political foundations are present with 58 offices in 20 countries. Likewise, the six German political foundations are widely present in the economically relevant group of countries knows under the acronym BRICS (Brazil, Russia, India, China and South Africa). Except for HSS, which is missing in Brazil, and FNS, which has no office in China, the remaining six, FES, FNS, HBS, HSS, KAS and RLS, are present in Russia, India and South Africa.

On the other hand, there are countries like Nepal in which only one foundation is located, where FES has an office since 1995 run by a local representative and five local employees which, according to its own website, runs the following main activities:

- Encouragement to the growth of democratic institutions and instruments...

- Promotion of dialogue on various issues concerning Nepal's environment, decentralization and good governance, civic education, women and development, economic policies, foreign aid, social issues, consumer rights, role of NGOs and civil society and international cooperation

- Improvement of labour welfare...

Scholarship support to promising young Nepali intellectuals to get exposure, training and education abroad ${ }^{4}$.

The educational mission of German political foundations is embedded into a very unique way of functioning when compared to other humanitarian organizations that aim for cross-border educational transfer by means of humanitarian aid in education, educational exports or educational exchange programmes.

- Different from humanitarian or philanthropic foundations, these organisations are party-related which means that they have an ambivalent status between legally 
autonomous organisations operating along their own agenda and at the same time by their strong connection to - if not dependence on - a particular political party. Every political party which is at present elected into the German Parliament has its own foundation, which adheres to the philosophy of the party and holds regular contacts to it. This implies that their political outlook is strongly influenced by specific political ideologies of the party to which they are affiliated. Consequently, this also implies that their 'political education' tends to be politically biased in favour of their party ally.

- Party-related political foundations are a rather unique type of organization situated between governmental influence and non-governmental approach. They are publicly funded and have to abide by the rules established by the Federal Government of Germany, which places them - though legally independent - under or at least very near governmental control. In any case, if not really 'non-governmental', they are definitely non-profit making organisations. But in this they aretotally dependent on the public budget which amounted to $€ 376.036 .000$ in 2012, most of which ( $€$ 270.337.000) went into their Auslandsarbeit and most of which (91.5\%) was coming from the BMZ and the rest from the Foreign Office (AA; details in Adick, 2014, p. 160). Their strong determination for Auslandsarbeit and their specific inclination to propel democracy education as part of Germany's foreign policy makes them very challenging for discussions on varieties of international education and comparative research.

- All of them have offices overseas with KAS and FES being practically known all around the world (Pogorelskaja, 2009a, pp. 294-295). Their Auslandsarbeit, i.e. their work abroad as compared to their Inlandsarbeit, i.e. what they do in Germany, occupies a major role in their existence since about the 1960s, when the German Foreign Policy began to establish contacts, administrative structures and policies towards the emerging or developing countries. In this new set-up, the political foundations were deemed apt and were financed for spreading the message of democratic enlightenment by means of various forms of non-formal political education around the world. At times, this has provoked the criticism of a 'self-service' system because the political parties as members of parliament decide on the state financing of 'their' respective foundations (Bartsch, 1998, p. 186, footnote 2). This means that their finances are not so contested as the ones of other 'real' NGOs relying on fundraising, sponsors and subsidies of the public budget. In fact, a ten-year survey (2000-2010) of the German Federal Court of Auditors showed some fluctuations, but the existing system of public financing of the foundations was not altered ${ }^{5}$.

- Although political foundations do exist in many countries today, it has to be stressed that the very special type of party-related organisations originated in Germany and has later been adopted in other nations, at times with explicit support from the Ger- 
man side (Bartsch, 2001, p. 218, footnote 21; Optenhögel, 2002, p. 128) like the US-based National Endowment for Democracy or the French Fondation Jean-Jaurès and Fondation Robert Schumann. "As far as size and funding are concerned, however, none of these organizations comes close to their German counterparts" (Bartsch, 2001, p. 219). This and the fact that German political foundations are also most influential in the European Network of Political Foundations (Kuhn, 2011, p. 294) offers the possibility to analyse them as 'models,' which were copied by other nations. Consequently, it may be presumed that their main contribution to proliferating democracy education abroad consists in offering political education without overt political interference.

- These German political foundations seem to score high in international esteem, as has been demonstrated from research conducted by International Relations Program of the University of Pennsylvania as part of their "Think Tanks and Civil Societies Program." Considering the ranking for the year 2011 (McGann, 2013), the following results can be highlighted: Out of $\mathrm{N}=5,329$ think tanks worldwide, $\mathrm{N}=194$ were from Germany, which were ranked in various categories, the category "best party affiliated think tanks" included all of the German political foundations: KAS (1st), FES (2nd), HBS (3rd), FNS (6th), HSS (8th) and RLF (21st) (McGann, 2013, p. 67). In the Top Fifty (non-US) think tanks worldwide, the following of them are listed: FES (11th), KAS (19th), and FNS (50th) (McGann, 2013, pp. 34-35). Notwithstanding the contested value of such rankings, the results in any case do indicate that research on their programmes and activities in the realms of 'political education' may be considered worthwhile and relevant especially for comparative education.

\section{Remarks on Existing Research on German Political Foundations}

How is the work of German political foundations discussed in the international scientific community? Generally speaking, research on the German political foundations is rather scarce with a lot of publications coming from the organisations themselves, like reports of varying kinds, which are descriptive and that have compiled synoptic views without any outspokenly empirical research design, be it qualitative, quantitative or the one that adopts a mixed methods approach. Relevant for research is the fact that a lot of primary sources concerning the structure, programmes, finances and activities of the organisations can be easily accessed online in English, since five of the six organisations have websites of their headquarters in English ${ }^{6}$. Some of them also publish websites and reports in their host countries in other languages, such as the websites of FES, KAS, HBS and RLS in Mexico written in Spanish. Another example is the FES office in Nepal, which, according to the publications list of its website, offers publications in English and in Nepali. 
Apart from primary sources most of the research on these organisations has hitherto been published in German. However, it may be observed that since about the turn of the century a number of articles in English have been published which might pave the way for more international attention. ${ }^{7}$ Some of these will be mentioned here in order to give nonGerman speaking readers a first overview of this literature.

"Linking the Worlds of Foreign Policy and Transnationalism" - this is how Bartsch (2001) characterizes the German political foundations. This view stresses the fact that whereas governmental activities are bound to the official foreign policy and restricted to instruments of political diplomacy, these foundations complement the state's foreign policy goals, as they have access to the state as well as the non-state actors in their international activities.

Several publications by Dorota Dakowska focus on party affiliated foundations as transnational actors in the European Union. In one of her articles, the author takes the example of Poland joining the EU and analyses the influences of KAS and FES in this process (Dakowska, 2002). She also points to the fact that the German political foundations do not only have offices abroad, but also an official representation at the EU in Brussels (Dakowska, 2002, p. 286). In another article, she argues that studies on the process of EU enlargement are mostly government-centred (Dakowska, 2005) or restricted to intergovernmental research perspectives. Publications would thus largely exclude transnational actors such as the German political foundations and others, which act across borders and influence the transformation and integration of newcomers into the EU. The German political foundations appear as very specific in mediating cooperation between national parties and the European party federations in the EU. This line of argumentation is continued by focusing on the general influences of national political party foundations on the formation of European party federations, which are affiliated to the European Parliament (Dakowska, 2009). For instance, the Centre for European Studies is the transnational political foundation of the European People's Party or the Foundation for European Progressive Studies is aligned to the Party of European Socialists (Dakowska, 2009, p. 214). Considering this process, she concludes that "The German political foundations are interesting case studies for the analysis of transnational networks and informal politics in Europe. Their involvement in the transnational promotion of democracy and their resources are unparalleled in most other European foundations" (Dakowska, 2009, p. 205).

In a research on eleven pan-European (as opposed to national) political foundations, which thematically overlaps with Dakowska (2009), the authors Gagatek and Van Hecke (2011) mention that these newcomers in the field of political foundations operate with comparatively low numbers of personnel and financial budgets if compared to the German model institutions which these authors find "exceptional in the amount of resources they possess" (p. 6). 
Brucker (2007) stresses the transnational agency of German political foundations in an article on the 'Orange Revolution' in Ukraine. The author recalls that mostly national actors and domestic influences are focused in explanations, whereas transnational actors tend to be overlooked or are suspicious of a "Western-funded conspiracy" (Brucker, 2007, p. 297). He analyses the democratising advances of FES, HSS and KAS, which were present in Ukraine since early 1990s (Brucker, 2007, pp. 308-314), stressing the interplay between external and internal influences. Without going into detailed definitions, Brucker (2007) calls the foundations transnational 'norm entrepreneurs', meaning "agents with strong ideas about the right behaviour in their community" (p. 301).

Pérouse de Montclos (2012) who researched the presence of KAS and FES in Nigeria on the basis of field observations and expert interviews, notes that these foundations are active in Nigeria, even though their success in imparting principles of good governance is questionable due to the lack of evaluations or empirical research. He concludes that actually the proclaimed democratising mission of the foundations cannot really explain their presence in a foreign country, but instead their primordial aim appears to be "relaying the diplomatic interests of their home country. German political foundations play the role of 'parallel' embassies, which are more flexible than accredited diplomats" (p. 241). This, again, points to the strong interplay between the foundations and German foreign policy goals in these countries.

\section{Which Type of Education Do These Organisations Offer? Evidence From Research}

Important for the topic discussed here is a review of literature devoted to the study of what the German political foundations do with respect to 'education' (in a rather broad sense) in their work overseas. ${ }^{8}$ In the self-portrayal of the organizations, for example, in their websites and brochures, as well as in their publications, 'education' comes under different names including terms like 'democracy assistance/aid' (e.g. Mair, 2000; Mohr, 2010). Originally, in Germany, the overall mission of these organisations was named political education (politische Bildung) - directed at the Germans to teach them democracy. Later this mission became prominent in the international activities of the same foundations. Even though the organisations in their English language statements or literature in English sometimes describe their respective activities as 'civic education', we decided to keep the term 'political education' because it more aptly describes the double nature of their 'political education': on the one hand, it is an education about political matters and, on the other hand, it is a political action in itself as it seeks to transmit the specific worldview or ideology of each foundation to the target population abroad (Adick \& Giesemann, 2014). Research on the educational aspect of the German foundations will now be sketched.

A case study about the socio-political work of KAS in India was carried out by Schürmann (1989) on the question if KAS could be seen as a 'political arm' of German foreign and development policy by conducting a case study on a training program for rural 
youth. Methodically the author worked inter alia with interviews of the staff, observations and information of KAS and its partner organisations in India, the 'Indian Institute for Youth Welfare' (IIYW). In this case study, Schürmann illustrated the funding process of the IIYW through KAS and showed that KAS had succeeded in supporting IIYW in such a way that they could sustain themselves after the financial support ended.

According to Spitzenpfeil (1996), international activities of these foundations mirror BMZ policy, with 'political education' (gesellschaftspolitische Bildung) being one policy goal and 'social-structural assistance' (Sozialstrukturhilfe) another (pp. 46-48). The foundations financially support formal associations, informal groups and individuals in the society of the host country, like youth associations, political parties and trade unions, scholars, journalists, research groups, business associations and others. Their projects can be very diverse as long as they adhere to the principles of democratic order and to the particular ideology of each foundation, that is, their respective Christian, liberal, social democratic, ecological or socialistviews. The author adds that even though such aims may be valuable from a 'Western' point of view, they might nevertheless be felt as a kind of "cultural imperialism" by the recipient countries (Spitzenpfeil, 1996, p. 47). In her dissertation, Spitzenpfeil presents findings on the main regions and sectors of activity of the foundations using the data until about 1994 (pp. 86-100). For instance, FNS had been active mostly in Latin America until approximately 1983, but re-shifted budget allocations to Eastern European regions after the end of the East-West-conflict. It concentrated its efforts in the sectors of adult education, political dialogue, self-help organisations and media assistance.

Mair (2000) commences his article on the German political foundations by saying "The German political foundations (Stiftungen) are without a doubt among the oldest, most experienced and biggest actors in international democracy assistance. The more surprising fact is that the literature available on the international work of the German foundations is rather limited - not only in English but in German as well" (Mair, 2000, p. 128). In this survey (in which the FES, FNS, HBS and KAS filled his questionnaires), the author on their democracy assistance found, among other things, that they all concentrate their work on NGOs and tend to support interest groups and political parties, with the exception of HBS which seems more devoted to advocacy and self-help. And concerning the subject being discussed in this article, he concludes "All the foundations consider civic education a top priority of their democracy programs" (p. 134).

Egger (2007) posits that in the 1990s these foundations shifted from the abovementioned social-structural assistance (which is more costly) to projects that support local elites (Elitenförderung), targeting those in charge of making decisions, political elites, middle and higher management personnel etc. (pp. 51-53). Instruments in these cases are seminars, conferences, workshops, study tours, publications, scholarships, experts' meetings, etc., i.e. wellknown formats which are closely related to education. Similarly, 
views from inside the educational work of the political foundations are given by Fuchs (2007), chairwoman of FES in 2003-2010. Fuchs stresses that the main aim of the educational work in Germany and abroad is to strengthen democracy. The foundations realise this goal according to their political self-concept. She considers the worldwide network of the political foundations and their contact with political elites as outstanding characteristics of their international work (p. 146).

Loaeza (2007) presented a case study on the influence of the KAS in Mexico which in her view counters research of the 1980s which had doubted KAS' success in furthering democracy in Mexico (p. 48). Instead, the author stresses - among other findings - the high potential of the broad range of activities of the political foundations such as seminars, consultations, speeches, trainings, debates, expertise, publications, special leadership programs and other means of promoting civic education stressing that leadership programs "may be their most powerful instrument of influence, because they define the ideological and programmatic identity of political parties" (Loaeza, 2007, p. 55). She also mentions some differences when comparing the political foundations with other transnational NGOs, because

... their goal is institution-building whereas, for instance, the goal of think-tanks may be purely scholarly research and academic debate and policy-making; while human rights institutions are more interested in non-institutional ends, organizing civil society groups or mobilizations. There is also an important difference between think-tanks and human rights groups and political foundations, in that their networking with local actors targets economic, academic, and political elites; think-tanks have more restricted targets - mainly the academic community or business and governments; while human rights organizations work with the wider social groups. (pp. 55-56)

Even though her article concentrates a lot on party politics, it can be concluded that such impressions of researchers not devoted to education can be incentives for more detailed educational research.

An overview of German political foundations acting in Mexico (all six, with only HSS missing) has been published by Adick and Emmerich (2013). By placing the work of these organisations under theoretical concepts of transnationalism, the authors came to classify them as transnational educational organisations which operate in transnational educational spaces. A qualitative content analysis of the educational programs of various formats for one year (2012) that were being offered by FES (34 programs) and KAS (37 programs) was conducted (Adick \& Giesemann, 2014). The analysis of each organisation's programs encompassed two dimensions of 'political education': the content of education on political topics (political education as an education about political matters) and the political outlook as mirrored in targeted partners and addressees (standing as an indicator for the inevitably non-neutral political inclination of the political education offered by these organisations). The analysis also discusses different formats of educational programmes being applied by 
FES and KAS and found that all formats (a) focus on a certain subject, (b) are moderated by experts/speakers (c), address a special group of people, and (d) are usually free of charge. On average, the programs last half a day, except for conferences which last up to three days. The contents are national (issues of the host country) as well as regional (with regional or continental themes) and global. For example in 2012, FES Mexico as well as KAS Mexico discussed presidential elections as a national and G-20 summit as a global topic. Furthermore, the foundations organize educational visits and exchange programs for local partners to Germany and/or to other countries. In Mexico, special formats were also practiced by both FES and KAS which are called diplomados and can be described as further training courses that consist of several single teaching events which are coordinated and mutually complementing each other. Fees have to be paid and the course concludes with a certificate. Participants are emerging managerial political staff. On the one hand, these special education formats serve as an instrument for the foundations to further the participants' career and, on the other hand, they serve as the foundations' exertion of influence on the political elites of the host country.

Despite a limited number of analyses, it may be assumed that so far there is hardly any educational research devoted explicitly to political education performed by the German political foundations abroad. The topic only appears indirectly in some publications which mainly focus on the organisations from Social or Political Sciences perspectives. This reluctance or disinterest may stem from the pre-dominance of what has been called "the nation-state paradigm" in Comparative Education research (Adick, 2005, pp. 244246) - Education in foreign countries and comparisons of educational systems around the world are conceived as 'national' in character and they are mostly restricted to the sector of formal schooling, normally considered as the core of 'national education system'. This focus on national education systems, however, excludes (a) non-national actors as well as (b) educational arrangements that take place outside the school. If the German political foundations are to be analysed as educational organisations acting overseas, then, the research perspective needs to turn to transnational actors and to include non-formal education. One could add that much of what is offered by these foundations would fit into the very broad category of 'lifelong learning' which is often discussed today.

\section{Summary and Suggestions for Future Research}

On the basis of the aforementioned literature review and our own research, the concluding part of this article will begin by highlighting the main characteristics of the type of education which is offered by German political foundations. This will be followed by some suggestions for future research related to perspectives which have hitherto been neglected. 


\section{Non-formal Education}

The educational mission of German political foundations can be seen as political continuing education. Notwithstanding different contents and program formats being used, their programs take place outside the state-controlled education system and provide education in well-organized ways. Among the popular formats are workshops, seminars, dialogues, forums and conferences. Occasionally, there is a tendency to provide more formalized formats which result in longer training events, requesting applications and fees and even issuing some kind of certificates, as has been shown in the examples of FES and KAS in Mexico. The fact that non-formal education is not part of the 'official' education system of a given country should not be mistaken as a sign of low significance, because it can be influential. It should also be recalled that non-formal education has special chances of adapting to changing demands either of the organization or of the recipients and is, therefore, more flexible than any state-run school system.

\section{Party-related Democracy Education}

The uniqueness of the German political foundations lies not least in their distinct relation to a particular political party. Their relative autonomy also opens the way to cooperate with like-minded political parties overseas, where they are supposed neither to intervene overtly in favor of a particular political party nor into national political debates (Pogorelskaja, 2009a, p. 298). Abroad, the foundations cooperate with local partners and parties who share their political orientation. Among the partners are universities and academic institutions, NGOs, and media organizations. Because of the close cooperation with selected partners, the foundations' educational mission is not neutral, but politically and ideologically bound to particular values. Being party-related also means that the educational mission of these foundations is largely defined by the philosophy of the affiliated party in Germany.

\section{Political Education Close to German Foreign Policy}

Although acting as autonomous bodies, the foundations routinely conference with the $\mathrm{BMZ}, \mathrm{AA}$, and also with the German embassies in the countries in which they have their offices, which shows their embeddedness into official German policies (Pogorelskaja, 2002, p. 36). Pogorelskaja further highlights that there is some debate with regard to whether one should consider the interventions of these foundations as partnership or as external imposition on the countries where they operate (p. 37). Moreover, their heavy dependence on the BMZ and AA has resulted in calling them an "auxiliary support for the Federal Government's foreign policy" (Bartsch, 2001, p. 206). As had been shown above, there is a strong geographical overlap of German Embassies and foundations which one finds in the territory of over half of the countries in the world. The close entanglement with the official German foreign policy makes these political foundations a very specific type of border 
crossing organization in comparison to other philanthropic, humanitarian and non-state organizations.

Finally, we want to conclude by hinting at some areas of future research, which might be promising especially in comparative and international educational research fields. In our opinion, the following three areas have been neglected so far.

\section{Understanding the Recipient Side}

As stated above, the educational programmes of these organisations target democracy assistance by addressing the elites of the host country who seem to be suitable partners and share the ideology of the respective political foundation. Apart from gathering documentary evidence to prove their accountability and efficiency (e.g. for KAS: Maier, 1993, for FES: Mayer, 1993), more research could be directed to the participants of different programs, their motivation to participate, what they felt they learnt at the end of these programmes, their suggestions of didactical arrangements of various formats. It may be observed that most of the literature is written from the 'donor' side, i.e. looking at what the political foundations do in other countries, what concepts they provide, etc. However, a look at the 'recipient' side is also needed. Such research could concentrate on the local teaching personnel, speakers, authors and seminar leaders in the host countries, how they view their role and their perceptions of international education. Perhaps students and young scientists of universities of those host countries, in which these organisations operate and have their branches, could be interested in such research focusing especially on the 'recipient' side of educational transfer as confronted with the official policy through the documentary evidence in the easily accessed English language websites of these organizations.

\section{Diversifying the Notion of 'Educational Transfer'}

Since education, even in a broad sense, is only marginally treated in most publications we have consulted, there are seldom any remarks on the specificity of the educational work of the political foundations compared to the concepts of other actors. In our own approach, we pointed to the political education of these organisations as a very specific, namely 'political' variant of international/cross-border education, compared to other variants such as education aid (humanitarian), education export (commodity), and education exchange (reciprocity). In our own terminology, the foundations' approach was labelled "a clientelistic variant of political education for democracy under the umbrella of German foreign policy" (Adick \& Giesemann, 2014, p. 365). The reason for this label is that elites (intellectuals, government officials, political and social activists etc.) are the main target groups of the foundations' programs abroad. Their close cooperation with and strong promotion of elites allows them a stronger exertion of influence on sociopolitical processes. Usually, the foundations do not address the general public. This is a 
big difference compared to the target groups in Germany, where the political foundations act as one of the most important (non-school) political educational institutions and also offer programs to the interested public (pupils, students, teachers, seniors etc.). But such ephemeral conclusions do not yet meet the criteria of a sound identification and comparison of different types of international education; instead it leaves room for a lot of research to be done.

\section{International Comparisons}

It has already been said that the German party-related political foundations have served as a kind of model for other nations to follow. Consequently, the chance has increased that in a given host country there are various foreign political foundations of different countries competing with each other for local addresses and partners (or 'clientele elites'). This could be a starting point to compare their respective philosophy and practice of political education. Scott and Walters (2000) evaluated US, Canadian and British political foundations ${ }^{9}$ including an analysis of their distribution of grants according to world regions. According to them, such grants are primarily directed to the following aims: a) building and supporting civic participation and education (23.6\% of grants); b) promoting and supporting worker rights and political participation (22.6\% of the grants); and promoting and protecting human rights (19.8\% of the grants). Other purposes clearly fall significantly behind these three central objectives (Scott \& Walters, 2000, p. 249). More comparisons of this kind including political foundations of other countries would be needed. One could also compare how the programmes of various political foundations vary according to the host countries in which they are offered. For instance, one could compare the pedagogical approach and programme contents in the so-called Third World countries to programmes between more equal partners within the EU or in European-American 'Transatlantic Dialogue' to see if the headquarters apply different levels of pressure in each context (Dakowska, 2002, 2005; Renvert, 2011). After all, political education of whomsoever always includes a competition of influence, power and prestige.

\section{Notes}

1 If not stated otherwise the basic information on the FES and the KAS and other German political foundations derives from their websites which generally contain descriptions of the history of the organisation, information on their policy and programs and online documents like yearly reports.

2 The article owes to results from own research of the authors, without duplicating articles published elsewhere (Adick \& Emmerich 2013; Giesemann 2013; Adick \& Giesemann 2014; Adick 2014). This research was conducted in the context of a larger international and interdisciplinary social science project which concentrated on cross-border staff mobility in German and in Mexican profit and non-profit organisations; main results published in Adick/ Gandlgruber/ Maletzky/ Pries (Eds.) 2014.

3 The analysis is based on the UN geographical classification of the world. cf. United Nations Statistics Division: Composition of macro geographical (continental) regions, geographical sub- 
regions, and selected economic and other groupings. http://unstats.un.org/unsd/methods/m49/ m49regin.htm

4 The following information is taken from its website (cf. http://www.fesnepal.org/about/fes_in_ nepal.htm). Among the partners with whom the FES Nepal cooperates/ cooperated are media organizations, trade unions aswell as academic institutions and NGOs (cf. http://www.fesnepal. org/about/partners.htm); websites accessed in February, 2015).

5 https:/www.bundesrechnungshof.de/de/veroeffentlichungen/bemerkungen-jahresberichte/ jahresberichte/2011 (last control: 11 February, 2015)

6 http://www.kas.de/wf/en/, http://www.boell.de/en, http://www.en.freiheit.org/Aktuell/790c/index. html, http://www.rosalux.de/english/foundation.html, http://www.hss.de/english.html

7 In any case, in our own research it was found that the number of publications in English on the German political foundations was much higher than on other actors of German foreign cultural and educational policy which were studied, namely the German Schools Abroad and the GoetheInstitutes - both of which are also well-known for their cross-border educational activities (Hahm \& Weiler 2014). In this article we will only consider publications in English since the turn of the century.

8 Their educational work within Germany and addressed to the German populace has occasionally been treated in publications, but will not be considered here.

9 They refer to the German political foundations in footnotes (Scott \& Walters, 2000, pp. 237, 254); however, while acknowledging that "Germany has had a system of stiftungen, or foundations engaged in international activities since the 1950s", it would not be correct to continue, as they do, by saying that this "has more recently focused on democracy promotion" (p. 237), because this had been the core right from the beginning throughout.

\section{References}

Adick, C. (2005). Transnationalisierung als Herausforderung für die International und Interkulturell Vergleichende Erziehungswissenschaft [Transnationalization as a challenge for international and intercultural comparative educational sciences]. Tertium Comparationis, 11(2), 243-269.

Adick, C. (2014). Transnational staff mobility in the German political foundations. In C. Adick, B. Gandlgruber, M. Maltezky, \& L. Pries (Eds.), Cross-border staff mobility. A comparative study of profit- and non-profit organisations (pp. 141-167). Houndsmill/ Basingstoke, England: Palgrave MacMillan.

Adick, C., \& Emmerich, G. (2013). Transnational political education: The German political foundations in Mexico. In M. Maletzky, M. Seeliger, \& M. Wannöffel (Eds.), Arbeit, organisation und mobilität [Work, organization and mobility] (pp. 483-513). Frankfurt, Germany: Campus.

Adick, C., \& Giesemann, M. (2014). Die politische bildungsarbeit deutscher politischer stiftungen im ausland am beispiel Mexiko [Political education of German political foundations abroad as in the case of Mexico].Bildung und Erziehung [Education and Upbringing], 67(3), 349-370.

Bartsch, S. (1998). Politische Stiftungen: Grenzgänger zwischen Gesellschafts- und 
Staatenwelt. In W.-D. Eberwein \& K. Kaiser (Eds.), Deutschlands neue außenpolitik [Germany's new foreign policy] (pp.186-198). München, Germany: R. Oldenbourg. Bartsch, S. (2001). Political foundations: Linking the worlds of foreign policy and transnationalism. In W.-D. Eberwein \& K. Kaiser (Eds.), Germany's new foreign policy: Decision-making in an interdependent world (pp. 206-219). London, England: Palgrave Macmillan.

Brucker, M. (2007). Trans-national actors in democratizing states: The case of German political foundations in Ukraine. Journal of Communist Studies and Transition Politics, 23(2), 296-319.

Dakowska, D. (2002). Beyond conditionality: EU enlargement, European party federations and the transnational activity of German political foundations. Perspectives on European Politics and Society, 3(2), 271-296.

Dakowska, D. (2005). German political foundations: Transnational party go-betweens in the process of EU enlargement. In W. Kaiser \& P. Staire (Eds.), Transnational European Union (pp. 150-169). London, England: Routledge.

Dakowska, D. (2009). Network of foundations as norm entrepreneurs: Between politics and policies in EU decision-making. Journal of Public Policy, 29(2), 201-221.

Egger, M. (2007). Die auslandsarbeit der politischen stiftungen: Zwischen entwicklungshilfe und transformationskontext [Political foundationsworking abroad: Between development aid and transformation context].Berlin, Germany: Freie Universität Berlin.

Fuchs, A. (2007). Weltweites netzwerk für soziale demokratie. Zur internationalen bildungs-, beratungs- und dialogarbeit der politischen stiftungen am beispiel der Friedrich-Ebert-Stiftung [Global network for social democracy: International education, consultation and dialogue of political foundations as in the case of the Friedrich-Ebert Foundation]. In K. Beck \& H. Heil (Eds.), Sozialdemokratische außenpolitik für das 21. Jahrhundert [Social decomcratic foreign policy for the $21^{\text {st }}$ century](pp. 138-147). Baden-Baden, Germany: Nomos.

Gagatek, W., \& Van Hecke, S. (2011). Towards policy-seeking Europarties? The development of European political foundations (EUI Working Paper RSCAS 2011/58). Florence, Italy: European University Institute.

Giesemann, M. (2013). Grenzüberschreitende bildungsarbeit deutscher politischer stiftungen am beispiel der Friedrich-Ebert-Stiftung und Konrad-Adenauer-Stiftung in Mexiko [Cross-border education of the German political foundations: Examples of Friedrich-Ebert Foundation and Konrad-Adenauer Foundation in Mexico] (Unpublished master's thesis). Ruhr-University Bochum, Germany.

Hahm, E., \& Weiler, A. (2014). Transnational staff mobility in educational organisations. In C. Adick, B. Gandlgruber, M. Maltezky, \& L. Pries (Eds.), Cross-border staff mobility. A comparative study of profit- and non-profit organisations (pp. 182-214). Houndsmill/ Basingstoke, England: Palgrave MacMillan. 
Kuhn, M. (2011). Auf dem Prüfstand [On Trial]. E+Z (Entwicklung und Zusammenarbeit) [Development and Cooperation], 52(7-8), 294-296.

Loaeza, S. (2007). The political dimension of Germany's unintentional power: The KAS and Mexican democratization. In A.-M. Le Gloannec (Ed.), Non-state actors in international relations: The case of Germany (pp. 46-69). Manchester, UK and New York, NY: Manchester University Press.

Maier, W. (1993). Wirkungskontrolle und nachhaltigkeit von entwicklungsprojekten der Konrad-Adenauer-Stiftung [Controlling effects and sustainability of development projects of the Konrad-Adenauer Foundation]. In R. Stockmann \& W. Gaebe (Eds.), Hilft die entwicklungshilfe langfristig? Bestandsaufnahme zur nachhaltigkeit von entwic klungsprojekten[Does development aid help in the long run? Inventory on sustainability of development projects] (pp. 159-166). Opladen, Germany: Westdeutscher Verlag.

Mair, S. (2000). Germany's Stiftungen and democracy assistance: Comparative advantages, new challenges. In P. Burnell (Ed.), Democracy assistance: International cooperation for democratization (pp. 128-149). London, UK and Portland, OR: Frank Cass.

Mayer, P. (1993). Die nachhaltigkeit von entwicklungsprojekten der Friedrich-EbertStiftung [Sustainability of development projects of the Friedrich-Ebert Foundation]. In R. Stockmann \& W. Gaebe (Eds.), Hilft die entwicklungshilfe langfristig? Bestandsaufnahme zur nachhaltigkeit von entwicklungsprojekten[Does development aid help in the long run? Inventory on sustainability of development projects] (pp. 167181). Opladen, Germany: Westdeutscher Verlag.

McGann, J. G. (2013). 2012 global go to think tanks report and policy advice: Think Tanks and Civil Societies Program, University of Pennsylvania. Retrieved from http:// repository.upenn.edu/cgi/viewcontent.cgi?article $=1006 \&$ context $=$ think_tanks

Mohr, A. (2010). The German political foundations as actors in democracy assistance. Florida, FL: Dissertation.com.

Optenhögel, U. (2002). Die politischen stiftungen [Political foundtions]. In C. Bertram \& F. Däuble (Eds.), Wem dient der auswärtige dienst? Erfahrungen von politik, wirtschaft, gesellschaft [To whom the foreign service? Experiences from politics, economy, society](pp. 125-140). Opladen, Germany: Leske + Budrich.

Pérouse de Montclos, M.-A. (2012). Nigeria, "democrazy", and the German political foundations. In B. Petric (Ed.), Democracy at large: NGOs, political foundations, think tanks, and international organizations (pp. 231-246). New York, NY: Palgrave Macmillan.

Pogorelskaja, S. W. (2002). Die parteinahen stiftungen als akteure und instrumente der deutschen außenpolitik [Party-related foundations as actors and instruments of German foreign policy]. Aus Politik und Zeitgeschichte [From Politics and Contemporary History], 7, 29-38.

Pogorelskaja, S.W. (2009a). Im ausland einmalig - Die politischen stiftungen [Unique abroad - The political foundations]. In K.-J. Maaß (Ed.), Kultur und außenpolitik: 
Handbuch für studium und praxis [Culture and foreign policy: Handbook for studies and practice] (pp. 293-304). Baden-Baden, Germany: Nomos.

Pogorelskaja, S.W. (2009b). Frei von den zwängen der tagespolitik: Die deutschen politischen stiftungen im ausland [Free from constraintsof daily politics: German political foundations abroad].Frankfurt am Main, Germany: Peter Lang.

Renvert, N. (2011). Die europäisch-transatlantische dimension der deutschen politischen stiftungen [The European-transatlantic dimensions of German political foundations]. Zeitschrift für Politikberatung [Journal for Political Consultation], 3(3-4), 347-362.

Schürmann, M. (1989). Zwischen partnerschaft und politischem auftrag: Fallstudie zur entwicklungspolitischen tätigkeit der Konrad-Adenauer Stiftung [Between partnership and political mission: Case study ondevelopment policy activity of the KonradAdenauer Foundation]. Saarbrücken/ Fort Lauderdale: Breitenbach.

Scott, J., \& Walters, K. (2000). Supporting the wave: Western political foundations and the promotion of a global democratic society. Global Society, 14(2), 237-257.

Spitzenpfeil, A. (1996). Der Beitrag der politischen stiftungen zur entwicklungspolitischen zusammenarbeit [Contribution of political foundations to development cooperation]. Frankfurt am Main, Germany: Peter Lang. 